Article

\title{
Analysis of Wavelet Coherence: Service Sector Index and Economic Growth in an Emerging Market
}

\author{
Ayhan Orhan ${ }^{1}$, Dervis Kirikkaleli ${ }^{2}\left(\mathbb{D}\right.$ and Fatih Ayhan ${ }^{3, *(\mathbb{D}}$ \\ 1 Economics Department, Faculty of Economic and Administrative Science, Kocaeli University, Kocaeli 41380, \\ Turkey; aorhan@kocaeli.edu.tr \\ 2 Department of Banking and Finance, Faculty of Economic and Administrative Science, European University \\ of Lefke, Lefke Northern Cyprus, TR-10 Mersin, Turkey; dkirikkaleli@eul.edu.tr \\ 3 Gonen Vocation School, Bandırma Onyedi Eylül University, Gönen, Balıkesir 10900, Turkey \\ * Correspondence: fayhan@bandirma.edu.tr; Tel.: +90-505-812-0554
}

Received: 17 October 2019; Accepted: 22 November 2019; Published: 26 November 2019

check for updates

\begin{abstract}
The present study aims to shed some light on the causal link between the Service Sector Index in the Turkish stock market and economic growth using a wavelet coherence approach. Thus, the present study determines whether the Service Sector Index leads to economic growth in Turkey and/or vice versa. Based on our aim, we use the wavelet coherence approach, which allows us to capture long-run and short-run causal linkages between the Service Sector Index and economic growth in Turkey, since the approach combines both time domain causality and frequency domain causality tests. The findings from wavelet coherence reveal that there is one-way causality running from the Service Sector Index to economic growth in Turkey at different frequencies and different periods between 1997 and 2017.
\end{abstract}

Keywords: service sector; economic growth; emerging market; Turkey; wavelet coherence

\section{Introduction}

The service sector, which has a key role in the economic growth and economic development stages of national economies, is one of the fastest growing sectors of emerging market economies. Especially in the last half century, the world economy experienced shifts from the industry sector to the service sector. In concordance with this, the service sector in the Turkish economy has increased in importance. With respect to whether it comprises a large share of GDP and has enabled a high level of employment, or offers high foreign exchange revenues through international economic transactions, the service sector has a qualification that is the basis for tracking growth and the macroeconomic performance of the Turkish economy. Added to this, the service sector currently is increasingly gaining weight in the stock market, accompanied by improvements in capital markets in Turkey.

Services can be simply defined as non-physical production of mainly intangible outputs for customers in order to be satisfy different needs and provide additional value. Services provide assistance, joy, happiness, consolation, or health to consumers. The service sector includes health, tourism, banking, real estate, education, transportation, and insurance. The service sector has a growing and expanding volume and economic importance in both developed and emerging economies. The service sector is a key sector to produce employment facilities and to increase national income levels. For example, in the USA, service sector employment accounted for 55\% of the total in 1929 and $54 \%$ of national income in 1948, while this ratio reached $81 \%$ in 2016 . Furthermore, the trade surplus of services reached $\$ 227$ billion in the USA in 2016. This significant growth in the service sector shows that this sector is of increasing global importance [1]. This study, which has chosen this topic as a 
research subject, has value since the importance of the service sector in developing countries will be examined through an updated methodology.

In the economics and finance literature, after the pioneering study of Schumpeter (1911), numerous studies have investigated the finance-led growth hypothesis [2,3]. The theoretical definition of the relationship between financial development and economic growth is that a financial system that works well can support economic growth more effectively. In this regard, a more developed financial system allows for provision of finance for profitable business investments, allocating resources in a more productive manner, and distributing investment risk. Achieving diversified financial instruments through financial development provides economic growth prominently by directing savings to investments [4]. In general, results of empirical studies on this issue have supported this related argument.

On the other hand, support for development in capital markets for economic growth is a remarkable part of the financial system. It has been pointed out that share prices, in particular, have an active role in the economy by various channels. From this point of view, an increase in share prices bolsters the trust of economic sectors and decreases uncertainties about the future economic situation. In other words, an increase in share prices signals to economic sectors about how the economy will grow in the future [5]. A significant amount of research analyzing this issue obtained results showing that share prices support the economy.

The goal of this study was to reveal the causal relationship between economic growth and share prices (Istanbul Stock Exchange Service Index) of tertiary sector companies in the Istanbul Stock Exchange using the wavelet coherence approach. The period that the study analyzed is 1997-2017.

\section{Literature Overview}

The relationship between financial development and economic growth is a popular issue. The foundation of the relationship between financial development and economic growth can be based on Schumpeter's work [2]. According to Schumpeter, banks can stimulate rapid industrial growth and economic development, thereby producing finance entrepreneurship [6]. More precisely, Schumpeter argued that the institutions operating in financial intermediation direct savings toward investments more effectively and more clearly, thereby supporting economic growth. In this respect, studies related to the impact of financial development and, just as importantly, development of stock markets on the growth of national economies, have gained wide currency. Especially throughout the last quarter-century, national economies' stock market development gained momentum through support of extensive liberalization of international capital movement. Stock market development provides investors' access to financial resources, and helps allocate resources effectively by means of national and international investment stimulation. In another perspective, a well-functioning stock market contributes to more sustainable economic growth for national economies and enables the establishment of an attractive financial system for international investors. In this sense, the development of stock markets has the characteristic of being a prerequisite for the development of the financial system as well as sustainable economic growth [7].

On the other hand, expanding the share of the service sector in national economies in the last half century has thus hugely increased the global output level of service sector firms, with a consequent rise in their importance for capital markets. In this context, studies that focus on the relationship between market capitalization of service sector firms in the stock market and economic growth have also gained wide currency.

In this respect, we can classify the literature into three groups as they are associated with this study. The first group of literature we classified includes several studies that focus on relationships between financial development and economic growth. The literature review about these issues is presented in chronological order in the following paragraphs.

There are different approaches to address the impacts of financial development on economic growth. The first is the finance-led economic growth approach, which is led by Schumpeter [2] and is 
from a supply-side perspective, where financial development triggers economic growth. Finance-led growth asserts that there is a causality from finance to economic growth. The other approach proposed by Robinson [8], which is a demand-side approach, posits that economic growth causes financial development.

According to the finance-led economic growth hypothesis, development of the financial system contributes to economic growth through fund inflow by providing capital accumulation and technological development infrastructure to economies. Therefore, the financial system should be developed for sustainable economic growth for developing countries. In this approach, which looks at the development of financial services from the supply side, it is revealed that there is a causal relationship from financial development to economic growth. With the development of financial services, entrepreneurs will increase their growth rate through financial development by making more productive investments [2,9-16]. The development of financial markets will provide effective resource allocation by mediating the reduction of information and processing costs, increasing the efficiency of investments, and increasing capital accumulation. Stiglitz [17] stated that countries in which the financial system does not develop will experience market failure problems due to incomplete competition and asymmetric information.

As an alternative to the finance-led growth approach, a demand-oriented view has been developed where economic growth increases the demand for financial services and thus the financial growth triggered by economic growth [3].

In this context, Luintel and Khan [18] tested the long-term causality relationship between financial development and economic growth using a multivariate Vector Autoregressive Regression (VAR) method for 10 developing economies. With reference to research results, they found a two-way causal relationship between financial development and economic growth in all countries.

Güngör and Yllmaz [19] conducted empirical analysis for the relationship between financial market development and economic growth with the help of quarterly data from 1987-2005 for Turkey. While the GDP share of credit for the private sector was preferred as a proxy variable for development in the banking sector, the GDP share of stocks traded on the Istanbul Stock Exchange was preferred for securities market development. Two different methods, the Johansen-Juselius cointegration method and the Granger causality method, were utilized in the research. With reference to the findings of the Johansen-Juselius cointegration test, there was a significant relationship between the banking sector and economic growth, and securities market development and economic growth, in the long term. On the other hand, the Granger causality test showed that there was a two-way causal relationship between securities market development and economic growth, and a one-way causal relationship between economic growth and banking sector development.

Soytaş and Küçükkaya [20] analyzed the relationship between financial development and economic growth via quarterly data of the 1991-2005 period for Turkey. The Toda-Yamamoto method was utilized in the analysis of causality relationships; action and reaction analyses confirmed the research findings. Results showed that the effect of financial development on economic growth was neutral, as was the effect of economic growth on financial development. In other words, shocks that happen in financial development and economic growth do not affect each other, but there is a causal relationship between them in the long term.

Asteriou and Spanos [21] reviewed the relationship between financial development and economic growth via panel data sets of EU-26 countries in their study that covered the 1990-2016 period. Two different periods, namely pre-crisis and post-crisis, were compared in their research. In terms of findings, financial development significantly affected economic growth when a crisis was not involved. It was expressed at the end of the research that financial development creates negative effects on economic activities in the crisis period.

Agheli and Hadian [22] analyzed the relationship between financial development, commercial development, and economic growth via the panel causality method for developing and emerging economies for the period 1980-2013. The GDP share of trading volume was preferred as the proxy 
variable of commercial development, and the GDP share of the total value of stock exchange securities, M2/GDP, and GDP share of private sector credit were preferred as the proxy variables of financial development. It was pointed out that commercial development was the reason for economic growth in a significant portion of the countries reviewed; however, the direction of economic growth varied by commercial and financial development. A two-way causal relationship was observed between financial development and economic growth; a two-way causal relationship was found between financial development and commercial development; and a one-way causal relationship was found from economic growth to commercial development in terms of the Turkish economy.

The second literature classification group includes several studies that focus on relationships between stock market development and economic growth.

In this context, Gürsoy and Müslümov [23] performed panel data analysis for the causal relationship between share market development and economic growth in 20 countries that were selected for the period 1981-1994. The Sims method was used in Granger causality analysis in a related study. The authors preferred GDP per capita as a proxy variable of economic growth, and a compound index including capitalization/GDP for share market development, transaction volume/GDP, and transaction volume/total capitalization as the proxy variable of share market development. It was found at the end of the research that there was a one-way causal relationship from economic growth to share market development in both the short and long term, and from share market development to economic growth in the long term. In addition to these, the relationship between share market development and economic growth was much stronger, especially in developing economies.

Kumar and Padhi [24] analyzed the effect of share market development on economic growth by panel data analysis. Related research, which scrutinized 27 growing economies for the period of 1995-2012, used market capitalization rate, the total marketing value of trading securities, and turnover rate as proxy variables of share market development. The real GDP growth rate was preferred as a proxy variable of economic growth. Since heterogeneity of data is in question in panel causality analysis, they applied the Dumitrescu-Hurling panel causality test. With reference to the research results, there was a one-way causal relationship from share market development to economic growth. Moreover, the research findings showed that the effect of the rate of turnover and total market value of trading securities that was the proxy variable of share market on economic growth was strong; thus, growth was positively affected. However, market capitalization, which was another proxy variable, did not have a similar effect on the economies reviewed.

Tıraşoğlu and Yıldırım-Tıraşoğlu [25] reviewed the relationship between share prices, bank credit, and economic growth for the January 1998-February 2013 period in Turkey. The Istanbul Stock Exchange (BIST) 100 index was preferred as the proxy variable for equities issued; private bank credit level was used as the proxy variable for bank credit. The Toda-Yamamoto causality method was used to determine causal relationships between variables. There were found one-way causal relationships from bank credit to equity securities, and from equity securities to economic growth.

Jahfer and Mulafara [26] aimed to identify the relationship between share price volatility and firms' dividend policies on the Sri Lankan stock market. The results of the study revealed that share price volatility and dividend policy were positively linked with each other. Moreover, dividend pay-out ratio had positive but insignificant impacts on the movement of stock prices on the Sri Lankan stock market.

Öztürk [27] analyzed the causal relationship between GDP and share prices (BIST 100, BİST Finance, BIST Service, and BIST Industrial indexes) by Toda-Yamamoto causality analysis via quarterly data for the period 1991-2015. From the research findings that were obtained by causality analysis in the VAR model with two variables, there were one-way causal relationships from BIST 100, BIST Finance, BIST Service, and BIST Industrial indexes to GDP. On the other hand, there was no causal relationship between BIST 100 index and GDP.

Saidi et al. [28] reviewed the effect of share prices and exchange rate on economic growth. The analysis that was conducted using quarterly data of the period 2004-2015 used the ARDL (autoregressive distributed lag) model. With reference to the research results, share prices and foreign exchange rate 
had an effect on economic growth. Moreover, it was found that the effect of share prices on growth was much stronger in comparison to the effect of the foreign exchange rate on growth.

Rouf [29] utilized the model to investigate the determinants of voluntary disclosures of information in the annual reports of listed companies in the Dhaka Stock Exchange. The findings of the study indicated that the level of voluntary disclosure was positively correlated with the total assets, the percentage of female directors, and the board leadership structure of a firm. Moreover, there was a negative correlation between the percentage of equity owned by the insiders of a firm and the level of voluntary disclosures.

Rossi and Fattoruso [30] focused on the Italian stock market to explore its behavior. They clearly underlined the existence of anomalies in the Italian stock market over the period of 3 January 2005-30 December 2015.

Munisi [31] investigated the determinants of capital structure of the non-financial firms listed on the stock exchanges of 12 Sub-Saharan Africa countries. The outcome of the study clearly revealed that the capital structure of the non-financial firms was negatively associated with profitability and tangible assets, while the capital structure was positively associated with free cash and firm growth.

The findings of Mansali and Daadaa [32] indicated that the main determinants of the underperformance of seasoned equity offering (SEO) firms were the market run-up and the proceeds from the SEO in Tunisia. Moreover, there was a decrease of risk after the offering, and an increase in risk before the offering.

Pradhan [33] tested whether there was a long-term causal relationship between share market development and economic growth for G-20 countries. A VAR model was utilized to determine Granger causality in the study, which covered the period 1980-2015. GDP per capita was used as the dependent variable; share market capitalization, the total value of trading securities, share market turnover rate, the number of companies trading in the share market, and compound index of share market development were used as the independent variables. It was concluded that the relationship between economic growth and proxy variables of share market development varied on the basis of countries in the G20 formation. This relationship was one-way in some of the related countries and two-way in others.

Pan and Mishra [34] analyzed the effect of share market development in the Chinese economy on economic growth by using the structural breakage and causality test. They found at the end of the analysis that the global financial crisis seriously affected both real and finance sectors of China. The Shanghai exchange was in a negative and stochastic relationship with the real sector in the long term; again, the effect of related exchange was at a low level for the real sector. On the other hand, findings of the Toda-Yamamoto causality test confirmed that economic growth supported the progress of the Shenzhen exchange.

Finally, a third literature classification group includes several studies that focus on the relationship between the service sector and economic growth.

In this context, Kim [35] asserted that services had an important role in developed economies. This paper examined the spatial quality of the service sector between 1958 and 1977 in the USA. According to the findings, the service sector, which was significantly related with economic growth, included commercial and professional services, as well as finance, insurance, and real estate in USA.

Khayum [36] discussed the relationship between the expansion of the service sector and other sectors in the USA by the input and output method. The findings revealed a decreasing relationship between sectoral dependence. It indicated that the service sector, which had a lower sectoral connection, had an increasing share in GDP. In addition, a reverse linkage relationship was found between the service sectors and the general sectors in the USA.

Okpala [37] investigated the contribution of non-industrial service sectors to the economy in 38 different African countries. The service sector indices had a significant effect on economic productivity. While the ratio of value-added services to GDP did not have a statistically significant effect, the annual average of growth in the service sector had a positive and statistically significant impact. 
Sultan [38] scrutinized the effect of tertiary sector growth on macroeconomic variables for 16 countries in Asia, America, Oceania, and the European Continent. There was seen some exceptional circumstances for small economies; a positive relationship was found between the share of the tertiary sector and per capita income. It could be said in this regard that level of income had a significant effect on service demand. Moreover, the relationship between economic growth and the share of the tertiary sector was also analyzed. Based on the findings in the first stage, the increase in the share of the tertiary sector decreased the economic growth rate but increased the economic growth rate in the second stage. A reverse functional relationship was observed between economic growth and the share of the tertiary sector in developing countries, which took a lower tertiary sector share in comparison to developed countries.

Noland et al. [39] inclusively analyzed the effect of the tertiary sector on economic growth for the Asia region. It was concluded that the tertiary sector occupied a huge place in terms of production and employment of the region, and contributed to the economic growth of the region.

Nasir et al. [40] aimed to investigate the relationship between the energy sector stock, oil prices, and the stock market using a time-varying vector autoregressive model. Their findings reveal that oil price shocks have negatively affected the stock market.

Uğurlu and Tuncer [41] reviewed the effects of industry and the tertiary sector on economic growth and employment for Turkey by input-output analysis. We can see in the light of these research findings that key sectors in terms of growth and employment mostly included the sub-sectors of the industry. Although the effect of growth in the tertiary sector on the economy was limited, some of the sub-sector branches could play a critical role in the progress of the economy.

\section{Materials and Methods}

The aim of this paper is to examine the time-frequency dependence of the service sector index in the Turkish Stock Market and GDP in Turkey. The wavelet method was used for this aim. Time and frequency domain methods were run in order to analyze causal linkages. However, it is generally accepted that it is not possible to obtain significant estimations for economic or financial data due to non-stationary structures of these data. Furthermore, provided that there are structural break(s) in the time series dataset, erroneous results are generally produced in cases of time-based conventional causality tests with fixed parameters. In this case, it is crucial for the modelling technique to determine where structural break(s) occur. There is also a different frequency domain approach called Fourier transform. The basic problem with this approach is that it focuses only on the frequency domain and completely ignores information that occurs in the time domain [42]. Wavelet techniques have introduced an important innovation regarding this issue, since they allow one-dimensional time data to be decomposed into the two-dimensional time-frequency domain [43]. This innovation provides the opportunity to reveal long and short term causal relationships between the variables used in this study.

The wavelet analysis has some advantages for economic research. It promises to:

"Decompose a time series into highly specified time scales, rather than the blunt categorizations of short-term dynamics and long-term trends of traditional methods such as error-correction models and co-integration relationships. And wavelet analysis also permits to retain relevant variable information that would be lost with traditional methods by taking differences of data. The wavelet transform is a mathematical instrument that ensure a time scale presentation of a signal in the time domain and is generally utilized to determine the place of the mutation point in non-stationary signals". [44]

Wavelet analysis is popular and one of the most used methods in signal analysis. This is because the time series does not provide an opportunity for rapid stationary control for the Fourier transform. Additionally, wavelet analysis offers practical information at the same time for time and frequency on different length scales. This technique provides a balance of time and frequency localization. The Morlet wavelet gives the position, density, and frequency of the wavelet spectral peaks, as well as information on the variation time of the stream flow series [45]. 
According to Kirikkaleli [46], a multi-scale decomposition method provides a natural insight for frequency-dependent behavior in order to reveal the relationship between the Service Sector Index and economic growth. The main innovation of wavelet techniques can be seen where the decomposition of one-dimensional time data into the bi-dimensional time-frequency range is permitted. This allows the present study to capture the long-run and short-run causal linkages between the variables. In order to indicate frequency-dependent behavior for examining the nexus between the Service Sector Index and economic growth, a multi-scale decomposition method can be used as a natural framework.

The wavelet model $(\psi)$ used in this study is an extension of the Morlet wavelet. The wavelet equation used in this study is shown in Equation (1).

$$
\psi(t)=\pi^{-\frac{1}{4}} e^{-i \omega_{0} t} e^{-\frac{1}{2} t^{2}}, p t, t=1,2,3 \ldots,
$$

where $t$ shows the place where the wavelet is operated on a time series with narrow observations.

Basically, the wavelet has two substantial elements: the first is time or location $(k)$ and the other is frequency $(f)$. The $k$ parameter has an important role to detect the exact location of a wavelet by relocating the wavelet over time, while $f$ monitors the distended wavelet for localizing different frequencies. From the transformation of $\psi$, the $\psi k, f$ parameter is obtained. The following equation (Equation (2)) refers to this transformation:

$$
\psi_{k, f}(t)=\frac{1}{\sqrt{h}} \psi\left(\frac{t-k}{f}\right), k, f \in \mathbb{R}, f \neq 0
$$

Time series data are in the form of $p(t)$ in Equation (3), where a continuous wavelet can be obtained from $\psi$ as a function of $k$ and $f$.

$$
W_{p}(k, f)=\int_{-\infty}^{\infty} p(t) \frac{1}{\sqrt{f}} \psi\left(\overline{\frac{t-k}{f}}\right) d t,
$$

The reconstructed previous time series $p(t)$ with the $\psi$ coefficient is converted to Equation (4).

$$
p(t)=\frac{1}{C_{\psi}} \int_{0}^{\infty}\left[\int_{-\infty}^{\infty}\left|W_{p}(a, b)\right|^{2} d a\right] \frac{d b}{b^{2}} .
$$

As in Equation (5), it is possible to obtain more information about the range of the time series by using the wavelet power spectrum (WPS).

$$
W_{p} S_{p}(k, f)=\left|W_{p}(k, f)\right|^{2} .
$$

The wavelet consistency approach is applied in this study. The main innovation of wavelet coherence according to standard correlation is that this approach allows the present study to see any correlation between the time series $p(t)$ and $q(t)$ in the form of unified time-frequency-based causality. In Equation (6), the cross wavelet transform (CWT) of the time series is shown.

$$
W_{p q}(k, f)=W_{p}(k, f) \overline{W_{q}(k, f)},
$$

The CWT of $p(t)$ and $q(t)$ series are shown, respectively, in $W p(k, f)$ of Equation (7). As Torrence and Compo [47] proposed, the squared wavelet coherence can be structured as in Equation (7).

$$
R^{2}(k, f)=\frac{\left|C\left(f^{-1} W_{p q}(k, f)\right)\right|^{2}}{C\left(f^{-1}\left|W_{p}(k, f)\right|^{2}\right) C\left(f^{-1}\left|W_{q}(k, f)\right|^{2}\right)}
$$


$C$ shows time and the smoothing process over time, with $0 \leq R^{2}(k, f) \leq 1$. When $R^{2}(k, f)$ approaches 1 , it shows that the time series variables are correlated with a certain scale, which are shown in the figures below in red color and surrounded by a black line. Furthermore, if $R^{2}(k, f)$ reaches 0 , it means that there is no correlation between the time series variables and is shown in blue color [48].

Nevertheless, the calculation of $R^{2}(k, f)$ does not give the opportunity to differentiate the positive correlation from the negative. Torrence and Compo [47] proposed a tool to investigate the wavelet coherence via deferment indicators in the fluctuation of two time-series [30]. Equation (8) is converted to show the wavelet coherence of the difference phase.

$$
\phi_{p q}(k, f)=\tan ^{-1}\left(\frac{\mathrm{L}\left\{C\left(f^{-1} W_{p q}(k, f)\right)\right\}}{O\left\{C\left(f^{-1} W_{p q}(k, f)\right)\right\}},\right.
$$

where L shows an imaginary operator, and $O$ shows the real part operator.

\section{Results}

As an initial step, based on the wavelet approach, the wavelet power spectrum was employed to identify the areas of high and low amplitude and also the magnitude of the volatility in a particular region in the time series variables. In this study, a scale of 32 periods was selected, since the dataset covers the period from 1997 Q1 to 2017 Q4 (84 quarterly observations). In Figures 1 and 2, the white cone-shaped curve shows the cone of effect, indicating a border beneath where the wavelet strength is influenced due to discontinuity, whereas the dark black shape shows a 5\% significant level assigned by Monte Carlo simulations. Figures 1 and 2 show findings from the wavelet power spectrum for the variables of GDP and service sector index in the Turkish stock market, respectively. As seen in Figure 1, GDP was significantly vulnerable in 1998 (at 0-4 periods of scale), 2000-2001 (at 8-11 periods of scale), and 2007-2008 (at 3-4 periods of scale). In Turkey, as is clearly seen in Figure 2, the service sector index in the Turkish Stock Market was mostly vulnerable between 1997 and 2006 at different frequencies.

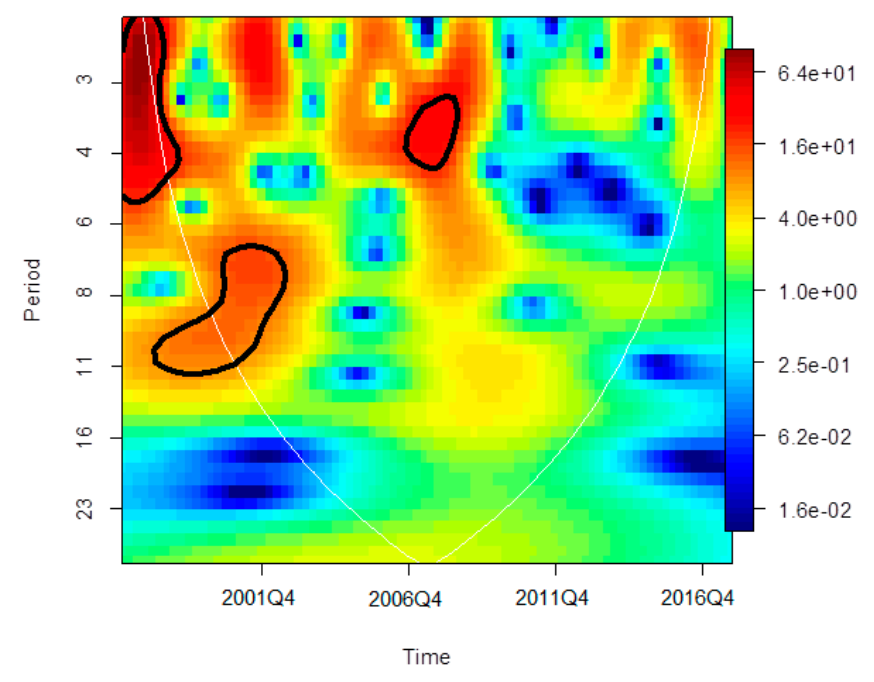

Figure 1. Power spectrum for GDP. 


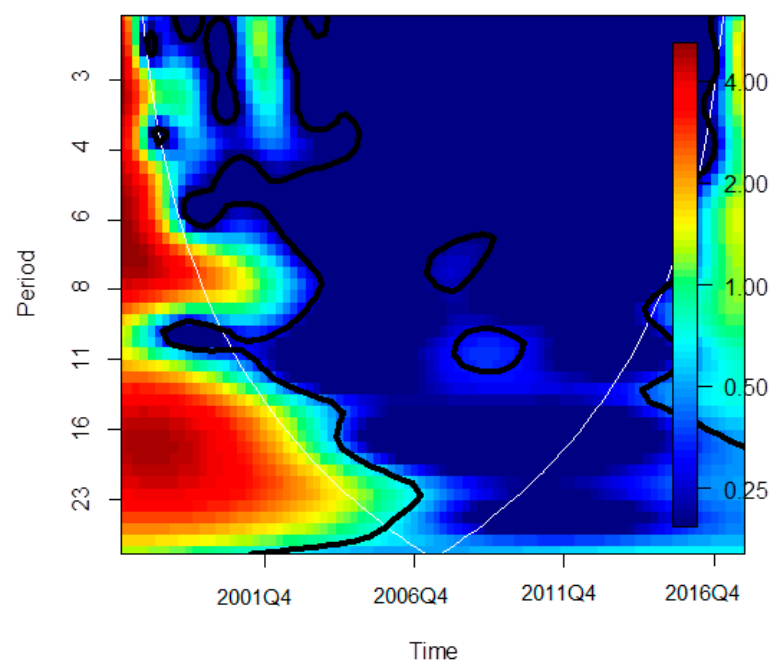

Figure 2. Power spectrum for Service Sector Index.

Figure 3 reports the wavelet coherence between GDP and Service Sector Index in the Turkish Stock Market. While the y-axis denotes the frequency, the x-axis shows the time. As in Figures 2 and 3 , the cone-shaped white line indicates the cone of impact. The color scale on the right side of the figure represents the level of correlation between GDP and Service Sector Index in the Turkish Stock Market. The red color indicates high correlations among the time series variables, while the thick black shape in Figure 3 indicates a 5\% significant level. An arrow in the wavelet coherence shows the lead/lag linkage between GDP and Service Sector Index in the Turkish Stock Market. While the arrow pointing to the left (right) indicates a positive (negative) correlation among the variables, arrows pointing up, right-down, or left-up mean that GDP causes the Service Sector Index in Turkey, while arrows pointing down, right-up, or left-down indicate that the Service Sector Index causes GDP. As clearly seen in Figure 3 , the findings from wavelet coherence reveal that there was one-way causality running from the Service Sector Index in the Turkish Stock Market to GDP in Turkey at different frequencies and different periods between 1997 and 2017, since the majority of the arrows point to the up or right-up within the cone-shaped white line. The causal effect was much stronger during the period of 2007 to 2017 relative to the period of 1997 to 2006. The outcomes obviously reveal how the Service Sector Index is important for predicting economic growth in Turkey.

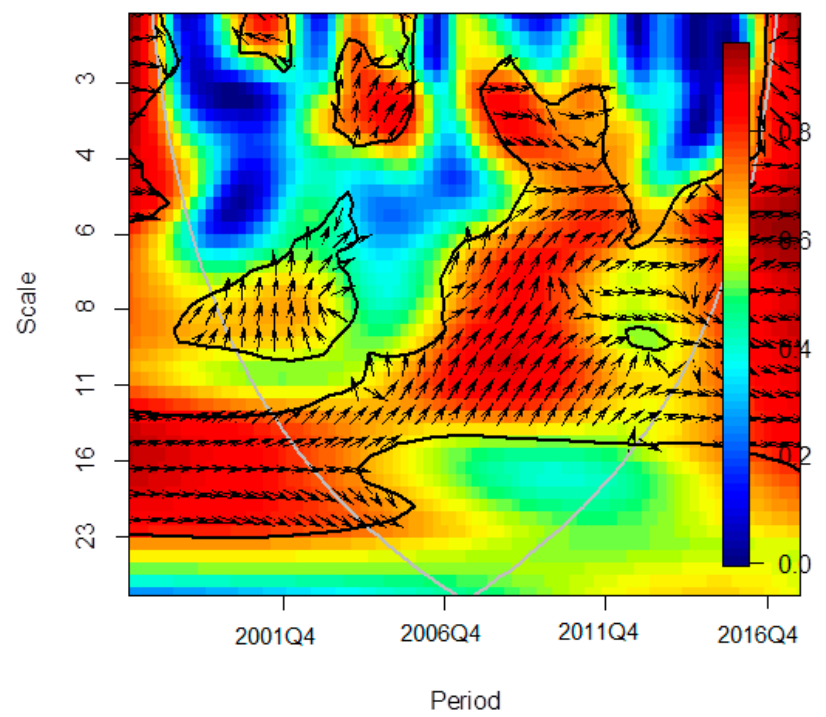

Figure 3. Wavelet coherence between GDP and Service Sector Index. 


\section{Conclusions}

It is well documented in the literature that the stock market plays an important role in the economy by various channels. In this study, we aim to investigate the time-frequency dependency of the Service Sector Index and economic growth in an emerging market, namely Turkey, using the wavelet coherence approach, which allows the present study to capture the long-run and short-run causal linkages between Service Sector Index and economic growth. A multi-scale decomposition method brings out a natural framework to show frequency-dependent behavior for investigating the linkage between Service Sector Index and economic growth. In the present study, we used a quarterly dataset, which covered the period 1997 Q1-2017 Q4. The empirical findings revealed that: (i) economic growth in Turkey was significantly vulnerable during the Asian crisis, 2000 banking crisis, 2001 currency crisis, and 2007-2008 global crisis periods, as expected, while the Service Sector Index in the Turkish Stock Market was mostly vulnerable between 1997 and 2006 at different frequencies; (ii) changes in the Service Sector Index led to change in economic growth in Turkey. Observing causal linkages from the Service Sector Index to economic growth in Turkey using wavelet coherence approach supports the findings of Sultan [38], Noland et al. [39], Kumar and Padhi [24], and Tıraşoğlu and Yıldırım-Tıraşoğlu [25]. The results can be used by policy makers to better understand how the service sector affects the economic growth in emerging markets.

Therefore, Turkish economy policymakers should continue to encourage service sector development, as should all emerging economies. More specifically, policymakers should try to place more emphasis on progressive services that may yield greater value addition benefits. Additionally, these services also tend to provide better technological transfer in additional to their nexus of development assistance with the rest of the economic sectors.

Although the present study makes it possible to identify strong empirical findings, further studies should be implemented in other emerging markets in the world, since the outcomes may be different from developed countries. Since the present study aims to explore the causal link between the Service Sector Index in the Turkish stock market and economic growth using the wavelet coherence approach, the present study did not use cointegration tests to capture long-run linkages among the variables and did not perfume time-series based regression models to capture the signs and sizes of the relationships among the variables. These are the main limitations of the study.

In particular, the direction of the relationship between the development of stock exchanges and economic growth obtained in future studies on the examples of emerging countries will guide the discussions on this issue. Therefore, detailed analysis of the similarities and differences of the results for future analyses of emerging countries will provide a solid basis for the formation of theory on this subject. There is a need for more studies with different emerging country examples, and different methods and time intervals.

The findings of this study reveal the importance of developed country financial markets and stock markets for both local investors' confidence in their own financial markets, developing financial markets, boosting the supply of funds and widening the investment potential, and improving the integration of international financial markets. The effects of the financial and stock markets on the economic growth of emerging countries should be tested on different countries and groups of countries with different and up-to-date methods in future studies. With the help of these future studies' contributions, it will be possible to derive and demonstrate a general theoretical and practical result regarding the relationship between financial markets and growth.

Author Contributions: Conceptualization, A.O. and F.A.; methodology, D.K.; software, F.A.; validation, D.K., A.O. and F.A.; formal analysis, D.K.; investigation, D.K.; resources, F.A.; data curation, A.O.; writing-original draft preparation, D.K.; writing-review and editing, F.A.; visualization, A.O.; supervision, D.K; project administration, A.O.; funding acquisition, A.O.

Funding: This research received no external funding.

Acknowledgments: We confirmed that this manuscript has not been published elsewhere and is not under consideration by another journal. In addition, we also confirmed that this research did not receive any specific 
grant from funding agencies in the public, commercial, or not-for-profit sectors. We have no conflicts of interest to disclose. Ethical approval and Informed consent do not applicable for this study.

Conflicts of Interest: The authors declare no conflict of interest.

\section{References}

1. Zeithaml, V.A.; Bitner, M.J.; Gremler, D.D. Services Marketing: Integrating Customer Focus across The Firm, 7th ed.; McGraw-Hill Education: New York, NY, USA, 2018.

2. Schumpeter, J.A. The Theory of Economic Development; Harvard University Press: Cambridge, MA, USA, 1911.

3. Kirikkaleli, D. Interlinkage between Economic, Financial, And Political Risks in the Balkan countries: Evidence from a panel cointegration. East. Eur. Econ. 2016, 54, 208-227. [CrossRef]

4. Mishkin, F.S.; Serletis, A. The Economics of Money, Banking and Financial Markets; Pearson Education: Toronto, ON, USA, 2011.

5. European Central Bank. "Stock Prices and Economic Growth". Monthly Bulletin October; European Central Bank: Frankfurt, Germany, 2012; pp. 47-50.

6. Graff, M. Financial Development and Economic Growth New Data and Empirical Analysis. METU Stud. Dev. 2001, 28, 83-110.

7. Carp, L. Can Stock Market Development Boost Economic Growth? Empirical Evidence from Emerging Markets in Central and Eastern Europe. Procedia Econ. Financ. 2012, 3, 438-444. [CrossRef]

8. Robinson, J. The Generalization of the General Theory. In The Rate of Interest and Other Essays; MacMillan: London, UK, 1952.

9. Gurley, J.G.; Shaw, E.S. Financial Aspects of Economic Development. Am. Econ. Rev. 1955, 45, 515-538.

10. Goldsmith, R.W. Financial Structure and Development; Yale University Press: New Haven, CT, USA, 1969.

11. McKinnon, R.I. Money and Capital in Economic Development; Brookings Institution Press: Washington, DC, USA, 1973.

12. Shaw, E.S. Financial Deepening in Economic Development; Oxford University Press: New York, NY, USA, 1973.

13. Fry, M.J. Money and Capital or Financial Deepening in Economic Development. J. Money Credit Bank. 1978, 10, 464-475. [CrossRef]

14. King, R.G.; Levine, R. Finance and Growth: Schumpeter might be 'Right'. Econ. J. 1993, 107, 771-782. [CrossRef]

15. Levine, R. Financial Development and Economic Growth: Views and Agenda. J. Econ. Lit. 1997, 35, 688-726.

16. Levine, R.; Zervos, S. Stock Markets, Banks, and Economic Growth. Am. Econ. Rev. 1998, 88, 537-558.

17. Stiglitz, J. Economic Growth Revisited. Ind. Corp. Chang. 1994, 3, 65-110. [CrossRef]

18. Luintel, K.B.; Khan, M.A. Quantitative Reassessment of the Finance-Growth Nexus: Evidence from a Multivariate VAR. J. Dev. Econ. 1999, 60, 381-405. [CrossRef]

19. Güngör, B.; Yılmaz, Ö. Finansal Piyasalardaki Gelişmelerin İktisadi Büyüme Üzerine Etkileri: Türkiye İçin Bir VAR Modeli. Ataturk Üniversitesi İktisadi ve İdari Bilimler Dergisi 2008, 22, 173-193.

20. Soytaş, U.; Küçükkaya, E. Economic Growth and Financial Development in Turkey: New Evidence. Appl. Econ. Lett. 2011, 18, 595-600. [CrossRef]

21. Asteriou, D.; Spanos, K. The Relationship between Financial Development and Economic Growth during the Recent Crisis: Evidence from the EU. Financ. Res. Lett. 2018, 28, 238-245. [CrossRef]

22. Agheli, L.; Hadian, G. Financial Development, Commercial Development and Economic Growth in the Selected Emerging and the Middle Eastern Countries. Int. J. Econ. Financ. Issues 2017, 7, 362-370.

23. Gürsoy, C.T.; Müslümov, A. Stock Markets and Economic Growth: A Causality Test. Doğuş Üniversitesi Dergisi 2000, 1, 124-131.

24. Kumar, P.; Padhi, N.P. On the Linkage Between Stock Market Development and Economic Growth in Emerging Market Economies: Dynamic Panel Evidence. Rev. Account. Financ. 2015, 14, 1-24.

25. Tıraşoğlu, M.; Yıldırım-Tıraşoğlu, B. Hisse Senetleri, Banka Kredileri ve Ekonomik Büyüme İlişkisi: Türkiye Örneği. Siyaset Ekonomi ve Yönetim Araştırmaları Dergisi 2015, 3, 21-30.

26. Jahfer, A.; Mulafara, A.H. Dividend policy and share price volatility: Evidence from Colombo Stock Market. Int. J. Manag. Financ. Account. 2016, 9, 97-108. [CrossRef]

27. Öztürk, F. Türkiye'de Hisse Senedi Fiyatları ve GSYİH Arasındaki İlişkinin Analizi. Uluslararası Yönetim İktisat ve İşletme Dergisi 2016, 30, 86-94. 
28. Saidi, L.; Adam, P.; Saenong, Z.; Balaka, M.Y. The Effect of Stock Prices and Exchange Rates on Economic Growth in Indonesia. Int. J. Econ. Financ. Issues 2017, 7, 527-533.

29. Rouf, A. Firm-specific Characteristics, Corporate Governance And Voluntary Disclosure In Annual Reports Of Listed Companies in Bangladesh. Int. J. Manag. Financ. Account. 2017, 9, 263-282.

30. Rossi, M.; Fattoruso, G. The EMH and the Market Anomalies: An Empirical Analysis on Italian Stock Market. Int. J. Manag. Financ. Account. 2017, 9, 222-241.

31. Munisi, G.H. Determinants of Capital Structure: Evidence from Sub-Saharan Africa. Int. J. Manag. Financ. Account. 2017, 9, 182-199.

32. Mansali, H.; Daadaa, W. Equities Issues and Long-Term Firm's Performances in Tunisian Stock Market. Int. J. Manag. Financ. Account. 2018, 10, 32-47.

33. Pradhan, R.P. Development of Stock Market and Economic Growth: The G-20 Evidence. Eurasian Econ. Rev. 2018, 8, 161-181. [CrossRef]

34. Pan, L.; Mishra, V. Stock Market Development and Economic Growth: Empirical Evidence from China. Econ. Model. 2018, 68, 661-673. [CrossRef]

35. Kim, J. Growth and Change in the Service Sector of the USA Spatial Perspective. Ann. Assoc. Am. Geogr. 1987, 77, 353-372.

36. Khayum, M.F. The Impact of Service Sector Growth on Intersectoral Linkages in the United States. Serv. Ind. J. 1995, 15, 35-49. [CrossRef]

37. Okpala, A.O. Knowledge Infrastructure, Service Sector, and Economic Growth In Africa. Int. Bus. Econ. Res. J. 2007, 6, 81-88. [CrossRef]

38. Sultan, M. The Tertiary Sector Is Going to Dominate the World Economy; Should We Worry? Munich Personal RePEc Archive: Munich, Germany, 2008.

39. Noland, M.; Park, D.; Estrada, G.B. Developing the Service Sector as Engine of Growth for Asia: An Overview; Asian Development Bank: Mandaluyong City, Philippines, 2012.

40. Nasir, M.A.; Rizvi, S.A.; Rossi, M. A treatise on oil price shocks and their implications for the UK financial sector: Analysis based on time-varying structural VAR model. Manch. Sch. 2018, 86, 586-621. [CrossRef]

41. Uğurlu, A.A.; Tuncer, İ. Türkiye'de Sanayi ve Hizmet Sektörlerinin Büyüme ve İstihdama Katkıları: Girdi-Çıktı Analizi. Dokuz Eylül Üniversitesi İktisadi ve İdari Bilimler Fakültesi Dergisi 2017, 32, 131-165.

42. Pal, D.; Mitra, S.K. Time-frequency contained co-movement of crude oil and world food prices: A wavelet-based analysis. Energy Econ. 2017, 62, 230-239. [CrossRef]

43. Kirikkaleli, D.; Gokmenoglu, K.K. Sovereign Credit Risk and Economic Risk In Turkey: Empirical Evidence From A Wavelet Coherence Approach. Borsa Istanb. Rev. 2019. [CrossRef]

44. Karlsson, H.K.; Li, Y.; Shukur, G. The Causal Nexus between Oil Prices, Interest Rates, and Unemployment in Norway Using Wavelet Methods. Sustainability 2018, 10, 2792. [CrossRef]

45. Wang, Q.; Liu, Y.; Tong, L.; Zhou, W.; Li, X.; Li, J. Rescaled Statistics and Wavelet Analysis on Agricultural Drought Disaster Periodic Fluctuations in China from 1950 to 2016. Sustainability 2018, 10, 3257. [CrossRef]

46. Kirikkaleli, D. Time-frequency Dependency of Financial Risk and Economic Risk: Evidence from Greece. J. Econ. Struct. 2019, 8, 37. [CrossRef]

47. Torrence, C.; Compo, G. A Practical Guide to Wavelet Analysis. Bull. Am. Meteorol. Soc. 1998, 79, 61-78. [CrossRef]

48. Kirikkaleli, D.; Ozun, A. Co-Movement of Political Risk and Sovereign Credit Risk: A Wavelet Coherence Analysis for Argentina, Brazil, and Venezuela. Soc. Sci. Q. 2019, 100, 2094-2114. [CrossRef]

(C) 2019 by the authors. Licensee MDPI, Basel, Switzerland. This article is an open access article distributed under the terms and conditions of the Creative Commons Attribution (CC BY) license (http://creativecommons.org/licenses/by/4.0/). 